Check for updates

1 Sheffield

Cite this as: BMJ 2021;375:n2778 http://dx.doi.org/10.1136/bmj.n2778 Published: 12 November 2021

\title{
Climate emergency: what should one do in the face of a failure of government?
}

\author{
As COP26 comes to an end, Bing Jones writes about why he took part in a public protest to highlight \\ the climate emergency
}

\section{Bing Jones former associate specialist in haematology}

Recently, I was arrested for obstruction of the highway after blocking a road. Peaceful disruptive public protest is a crude, inarticulate way to challenge government failure, but sometimes it feels like the only effective alternative to persistently ineffective objection. The climate crisis is terrifying, accelerating and irreversible. ${ }^{1}$ I am completely exasperated by society's collective failure to act at the pace and scale required. I am dumbfounded by the failure of informed people to influence toxic government delay. So, I've been sitting in the road.

Climate catastrophe is the biggest issue of our time. We are failing globally and failing in the UK. Global carbon emissions are not falling but rising. ${ }^{2} \mathrm{UK}$ terrestrial emissions are falling at about $1.5 \%$, but this excludes half of our genuine carbon footprint. ${ }^{3}$ If air travel, shipping and imported goods are included, UK emissions have only just peaked and may rise with economic recovery. ${ }^{4}$ We are nowhere near the $7 \%$ annual reduction required. ${ }^{5}$ The UK government continues to subsidise fossil fuels, cancel home installation initiatives and prioritise unsustainable growth. We expand roads for trucks and neglect public and active transport. We preach at climate conferences and set distant targets while failing to meet $80 \%$ of our current UK targets. ${ }^{6}$ Only governments can tackle climate change on the scale required and ours is pretending to do so, while obfuscating, delaying, and protecting fossil fuelled industries. What should one do in the face of a catastrophic failure of government?

It weighs heavy on me to have disrupted many ordinary people's lives and to have used valuable police time. But disruption brings media attention and national debate. Massive media coverage highlighting the government's failure to protect its citizens from avoidable calamity is long overdue. Interrupting fossil fuelled business-as-usual, the engine of the climate crisis, is a token of what is needed. The resolve and self sacrifice of peaceful individuals willing to face violence, fines, and prison is inescapable.

Something needs to be done about climate delay. We know what to do and there is money to do it: globally, we subsidise polluting industries by \$5.9 trillion annually. ${ }^{7}$ Radical action needs to start now, not in decades to come. We are living a lie and swimming in a sea of acquiescence. We passively accept the media's implicit messages of "it can wait" and "someone will fix it." Some worry, lobby, lecture, publish, or politicise. A few demonstrate with activists. But despite all this, policy and legislation show no sign of the immediate, radical change required. Our systems for influencing government policy are failing. The media portray existential threats as entertainment and pallid experts talk with statistics that most people cannot digest. The result is a collective complacency. I cannot sit by, something needs to be done to shake us out of our torpor. It will be unpopular.

Delay is expensive as well as cruel. We need to drop emissions by $7 \%$ annually. Instead, emissions are rising. With every month of delay the costs of rectifying climate damage increase. Estimates in 2020 of $18 \%$ of global GDP rise by 0.6 trillion US dollars for each year of delay. ${ }^{8}$ We cannot avoid enormous costs, but we can avoid delay. We have created irreversible climate change which we are failing to acknowledge. Each month of delay increases risks, damage, and cost, yet our government relies on empty promises, distant targets, and the very free markets which have fuelled this crisis.

Chatham House talks of total worldwide maize crop failures, a 95\% chance of exceeding a $2^{\circ}$ rise and millions dying annually from extreme heat. ${ }^{9}$ Yet, knowing these facts, we hang onto our belief in current institutions. We hang on to the illusion that we live in a logical society. Continuing to believe in systems that are not working is social suicide. We are all on the hamster wheel of "normal" life.

Government, the media, and commerce encourage us and we acquiesce. The government rearranges deck chairs with no sign of proportionate, urgent action.

Our heads are down and we're too busy to hear the fire alarm. There's smoke coming under the doors. A few people are shouting, pulling at clothes, and spilling coffee to raise the alarm. The suffragettes broke every window in Oxford Street, Martin Luther King was unpopular in his lifetime, and Gandhi was murdered. We did not get the vote by voting. Disruption is often needed to enable major societal change.

Disruptive, unpopular demonstrations rattle cages, but may spread a truthful, honourable message. Disruption may be more honest than silence. The climate crisis demands that we tell uncomfortable truths in ways that will be heard.

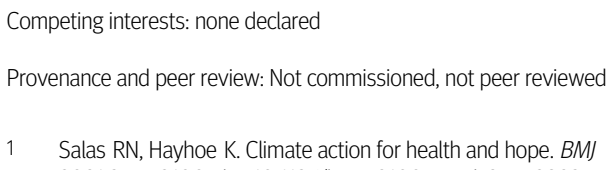

Salas RN, Hayhoe K. Climate action for health and hope. BMJ 2021;374:n2100. doi: 10.1136/bmj.n2100. pmid: 34452923 


\section{OPINION}

2 Global carbon dioxide emissions are set for the second biggest increase in history https://www.iea.org/news/global-carbon-dioxide-emissions-are-set-for-their-second-biggest-increase-in-history

3 Half U. K's true carbon footprint created abroad, research finds https://www.theguardian.com/environment/2020/apr/16/britain-climate-efforts-undermined-failure-imports-carbon

4 Exploring the UK's contribution to climate change https://www.wwf.org.uk/sites/default/files/2020 04/FINAL-WWF-UK_Carbon_Footprint_Analysis_Report_March_2020\%20(003).pdf

5 The global climate crisis and the action needed https://static1.squarespace.com/static/60ccae658553d102459d11ed/t/60d421c67f1dc67d682d8d29/1624515027604/CCAG+Launch+Paper.pdf

6 Climate Change Committee Progress report https://www.theccc.org.uk/publication/2021-progress report-to-parliament/

7 Fossil fuel industry gets subsidies of $\$ 11 \mathrm{~m}$ a minute, IMF finds https://www.theguardian.com/environment/2021/oct/06/fossil-fuel-industry-subsidies-of-11m-dollars-a-minute-imf-finds

8 Sanderson BM, O'Neill BC. Assessing the costs of historical inaction on climate change. Sci Rep 2020;10:9173. doi: 10.1038/s41598-020-66275-4. pmid: 32514079

9 Climate change risk assessment https:/www.chathamhouse.org/sites/default/files/2021-09/2021 09-14-climate-change-risk-assessment-summary-quiggin-et-al_0.pdf 